\title{
Canadian Council of Forest Ministers: Champions of sustainable forest management
}

\author{
by André H. Rousseau ${ }^{1}$
}

The Canadian Council of Forest Ministers (CCFM), established in 1985, is composed of the federal, provincial and territorial Ministers responsible for forests. Its role has evolved into one that stimulates the development of policies and initiatives for strengthening the forest sector, including the forest resource and its use. One of the most important functions of the CCFM is that it sets the overall direction for the stewardship and sustainable management of Canada's forests by addressing issues and stimulating joint initiatives. Under its guidance, four successive National Forest Strategies and three Forest Accords have been developed. Another major achievement has been the development of the CCFM Criteria and Indicators Framework: Defining Sustainable Forest Management - A Canadian Approach to Criteria and Indicators. Today, the CCFM works under five strategic themes: sustainable forestry; international issues; forest communities; science and technology; and information and knowledge. The ongoing, positive cooperation between the two levels of government helps maintain healthy and productive forests and their sustained contribution to Canadians' economic, environmental and social well-being over the long term.

Key words: stewardship, governments, collaboration, national framework for action, criteria and indicators, integrated information

Le Conseil canadien des ministres des forêts, constitué en 1985, regroupe les ministres provinciaux, territoriaux et fédéral responsables des forêts. Le rôle du Conseil en est devenu un de catalyse de l'élaboration de politiques et d'initiatives aptes à renforcer le secteur forestier ainsi que la ressource forestière et son utilisation. Une des fonctions les plus importantes du CCMF est de définir une direction d'ensemble pour l'intendance et la gestion durable des forêts du Canada, en traitant des enjeux et en favorisant des initiatives conjointes. C'est sous sa gouverne que furent formulés, quatre Stratégies nationales sur les forêts et trois Accords canadiens sur les forêts. Une autre réalisation marquante fut la mise au point du Cadre canadien de critères et indicateurs de l'aménagement durable des forêts au Canada du CCMF. Le Conseil poursuit maintenant ses activités selon cinq axes stratégiques, soit: la foresterie durable, les enjeux internationaux, les collectivités forestières, les sciences et la technologie, et, l'information et les connaissances. La coopération soutenue entre les deux paliers de gouvernement aide au maintien de forêts en santé et productives, ainsi que de leur contribution au bien-être économique, environnemental et social à long terme des Canadiens et Canadiennes.

\section{Mots-clés: intendance, gouvernements, collaboration, cadre d'action national, critères et indicateurs, information intégrée}

El Consejo Canadiense de Ministros de Bosques (CCFM) se estableció en 1985 y está compuesto por los ministros de los gobiernos federal, provincial y territorial a cargo de los bosques. La función actual del Consejo se centra en estimular el desarrollo de políticas e iniciativas tendientes a fortalecer el sector, especialmente en lo que respecta a los recursos forestales y su utilización. Una de sus funciones principales es determinar la orientación general para la conducción y manejo sustentable de los bosques de Canadá, identificando y abordando los temas que requieren atención y estimulando iniciativas conjuntas. Bajo su dirección, se han desarrollado cuatro Estrategias forestales nacionales sucesivas y tres Acuerdos forestales. Otro logro de importancia ha sido el desarrollo del Marco de Criterios e Indicadores del CCFM: Definiendo el Manejo Forestal Sustentable - Un enfoque canadiense a criterios e indicadores. Las actividades actuales del Consejo se centran en cinco temas estratégicos: silvicultura sustentable; asuntos internacionales; comunidades forestales; ciencia y tecnología; información y conocimiento. La cooperación continua y fecunda que se ha establecido entre los dos niveles de gobierno contribuye a preservar la salud y productividad de los bosques propiciando el bienestar económico, ambiental y social canadiense a largo plazo.

Palabras claves: conducción, gobiernos, colaboración, marco nacional, para acción, criterios e indicadores, información integrada

\section{Introduction}

The Canadian Council of Forest Ministers (CCFM) was established in 1985 to exchange forest-related information informally at the most senior levels in order to develop forest-related policies, to provide leadership across governments and to communicate Canada's importance as a forest nation, as a leader in forest science and technology and as a serious participant in the quest for sustainable forest management worldwide. Since that time, it has proven to be an important and unique forum in which members work cooperatively on forest issues of national and international concern.

${ }^{1}$ Director, Federal-Provincial Relations, Policy, Planning and International Affairs, Canadian Forest Service, Natural Resources Canada, Ottawa, Ontario K1A 0E4 (e-mail: ahrousse@nrcan-rncan.gc.ca).
The CCFM is composed of the federal, provincial and territorial Ministers responsible for forests. Its role has evolved into one that stimulates the development of policies and initiatives for strengthening the forest sector, including the forest resource and its use. One of the most important functions of the CCFM is that it sets the overall direction for the stewardship and sustainable management of Canada's forests.

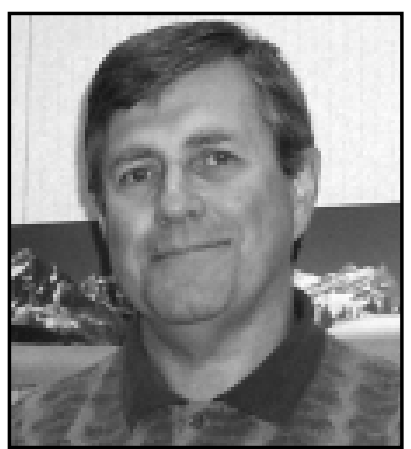

André H. Rousseau 
Its objectives are to:

- Share information on issues affecting the forest sector;

- Coordinate approaches to the strategic management of inter-jurisdictional and emerging issues of national and international significance;

- Cooperate in developing and maintaining the scientific information base required to support sound forest management decision making;

- Demonstrate international leadership on sustainable forest management;

- Promote forest management in Canada;

- Cooperate with other ministerial councils (such as the Wildlife, Endangered Species, Parks or Fisheries and Aquaculture councils) and fora, as appropriate, to address common issues.

The CCFM operates on four levels. The Ministers make political decisions and provide leadership, address national and international issues and set the overall direction for the stewardship and sustainable management of Canada's forests. The Deputy Ministers implement the Ministers' decisions, ensure initiatives are focussed, result-oriented and fit into the operating and performance frameworks of the CCFM. They administer the overall business of CCFM as well as identify and analyse emerging issues and provide advice and counsel to the Ministers. The third level is the Coordination Group that manages the five-year strategic plan and provides the annual report. The Group also analyses and reviews proposed new initiatives before submitting them to the Deputies or Ministers. The fourth level is composed of supporting committees: working groups, which focus on long-term, ongoing business, and task forces, which focus on specific, short-term initiatives that disband after completing the project.

The CCFM meets at least once a year. The Chair rotates every year based on a roster. Nova Scotia chaired in 2002, Canada is chairing in 2003 and Yukon will chair in 2004.

\section{Leadership in Sustainable Forest Management}

Sustainable forest management took the world stage in the 1980s as being one of the most important environmental issues of the day. Its rapidly growing importance strongly underlined the need for a dedicated body such as the CCFM to address forestry issues and the alternating praise and criticism of Canada's forestry practices happening at the time. The CCFM took responsibility as a national governmental voice and played an important catalytic role in promoting the sustainable management of Canada's forests.

\section{National Forest Strategies: Fulfilling National and International Goals}

By addressing issues and stimulating joint initiatives, the CCFM has gradually shaped the overall direction for the sustainable management of Canada's forests. Throughout the mid-1980s, the CCFM sponsored a series of public forums across Canada to discuss the state of the forest and its future. The results formed the foundation for a national Forest Sector Strategy for Canada (1987-1992). The CCFM then led the development of the first two National Forest Strategies, Sustainable Forests: A Canadian Commitment for 1992-1998 and for 1998-2003, through a series of public consultations that included a wide range of Canadian governments, organizations and groups.

\section{Box 1}

The federal, provincial and territorial ministers responsible for forests comprise CCFM membership:

- Minister of Natural Resources, Government of Canada

- Minister of Forest Resources and Agrifoods, Government of Newfoundland and Labrador

- Minister of Natural Resources, Government of Nova Scotia

- Minister of Agriculture and Forestry, Government of Prince Edward Island

- Minister of Natural Resources, Government of New Brunswick

- Minister of Natural Resources, Parks and Wildlife, Government of Quebec

- Minister of Natural Resources, Government of Ontario

- Minister of Conservation, Government of Manitoba

- Minister of Environment, Government of Saskatchewan

- Minister of Sustainable Resource Development, Government of Alberta

- Minister of Forests, Government of British Columbia

- Minister of Renewable Resources, Government of the Yukon Territory

- Minister of Resources, Wildlife and Economic Development, Government of the Northwest Territories

- Minister of Sustainable Development, Government of Nunavut

The 1992-1998 Strategy, presented at the Rio UNCED conference, was praised as being Canada's first truly national forest strategy. The Strategy also anticipated many of the concerns and suggested actions in what would become Agenda 21 (the United Nations' Global Programme of Action on Sustainable Development). The Strategy thus became, and continues today as, not only Canada's framework for actions to meet national goals for sustainable forest management, but also to meet its international forestry commitments.

The 1992-1998 Strategy had even further ramifications. Under the guidance of the CCFM, the National Forest Strategy Coalition (NFSC) was formed to oversee implementation of the Strategy from planning to communicating and reporting through to independent third-party evaluations. NFSC members are currently the 52 governmental and non-governmental organizations that signed the second Canada Forest Accord in 1998. The creation of the NFSC was a significant milestone in Canadian forestry. At the 9th National Forest Congress, held in May 2003, Canadians gave themselves their 5th National Forest Strategy 2003-2008, A Sustainable Forest: The Canadian Commitment. They also confirmed their commitment to continuing to work cooperatively toward this collective goal of a sustainable forest nationwide by signing the 3rd Canada Forest Accord. The 3rd Accord remains open to new signatories and the total number, which continues to increase, is anticipated to exceed that of its predecessor. Because it includes more than political leadership, Canada's forest-related commitments have strengthened and deepened as this broad representation assumes responsibility for the course of national achievements in the forest sector. 
Canada's National Forest Strategies and Forest Accords have been used by other nations as models for initiating and sustaining the journey toward sustainable forest management on a national scale.

\section{Assessing Performance: Criteria and Indicators of Sustainable Forest Management}

Another major CCFM achievement resulted from the recognition that the Forest Principles negotiated at Rio during UNCED created the need to formulate scientifically based, internationally accepted criteria and indicators of sustainable forest management. Criteria and indicators were defined in Canada as the basis for formulating, monitoring and reporting innovative approaches toward the management of Canada's forest as a series of continuing ecosystems and for monitoring and reporting Canada's achievements relative to the goals established under the National Forest Strategy. In 1993, the CCFM led this initiative by establishing the Steering Committee on Criteria and Indicators of Sustainable Management of Canada's Forests. Under this Committee, the CCFM embarked upon an open, transparent and inclusive process involving officials and scientists from the federal, provincial and territorial governments as well as experts from the academic community, industry, non-governmental organizations, the Aboriginal community and various other groups. This broad exchange of views ensured that criteria and indicators would be based on the best available knowledge. The result was the release, in March 1995, of the CCFM Criteria and Indicators Framework: Defining Sustainable Forest Management - A Canadian Approach to Criteria and Indicators. The CCFM C\&I Framework was designed to be compatible with other international criteria and indicators processes such as the Montréal Process for temperate and boreal forests and the Helsinki Process for forests in Europe. The CCFM C\&I Framework was an important step in implementing Canada's commitments embedded in the National Forest Strategy and in covering the forestry commitments made at UNCED.

\section{The Way Forward}

The CCFM continues to focus on a number of initiatives to develop and apply sustainable forest management practices. As of 2003, the CCFM is focussing on five strategic themes:

- sustainable forestry;

- international issues;

- forest communities;

- science and technology; and

- information and knowledge.

\section{Sustainable Forestry}

The CCFM recognizes that Canada's forests, a series of continuing ecosystems, are not restricted by political boundaries - the boreal forest, for example, stretches across the country - and that far greater advantage is derived by coordinating a common sustainable forestry effort and pooling resources rather than by individually trying to develop broad initiatives. In this context, the CCFM supports:

- wood fibre production from a dedicated land base;

- a level of protection for forest ecosystems that is both scientifically and socially acceptable; and

\section{Box 2}

In Canada, cooperation between the federal, provincial and territorial governments on forestry matters has a long tradition. The need for cooperation is based on the division of land jurisdictions and responsibilities. In Canada, nearly 94 percent of the forest is owned by the public, with 71 percent controlled by the provinces. Each province has its own legislation, regulations, standards and programs through which it honours its forest management responsibilities and assigns harvesting and other rights. Responsibility for international relations and trade, and federal and Aboriginal lands resides primarily with the federal government. The two levels of government share responsibilities in the areas of science and technology, industrial and regional development and the environment. The federal government works closely with the provinces in monitoring and reporting on the state of Canada's forests and forestry practices. Both levels of government work to maintain healthy and productive forests to ensure that they continue contributing to Canadians' economic, environmental and social wellbeing over the long term.

- greater stability and autonomy for communities, based on the responsible use of all forest resources.

The CCFM's Canadian Criteria and Indicators Task Force continues to guide the preparation of Canada's criteria and indicators reports on sustainable forest management. As well, the CCFM communications committee promotes the CCFM's position on sustainable forest management and ensures that the wording of public messages is consistent with that position.

\section{International Issues}

Because of Canada's prominence on the international forestry scene, the CCFM recognizes a need for a strong national voice in this arena. With nearly $10 \%$ of the world's forests supporting a sector that contributes about $\$ 34.4$ billion to Canada's annual trade balance, Canada must be active in the international policy dialogue. That dialogue is complex at times because it involves many instruments and processes that address various facets of forest management in individual countries and around the world. They include sustainable forest management, biodiversity, combatting deforestation and forest degradation, international trade, economic growth, climate change, national security, land use and land conservation.

The CCFM is called upon to facilitate the forestry implementation domestically of four international legally binding instruments: the Convention on Biological Diversity, the Framework Convention on Climate Change, the Kyoto Protocol and the Convention on the International Trade in Endangered Species of Wild Fauna and Flora (CITES). Through the CCFM's International Forest Convention Working Group, the CCFM has also been actively involved in pursuing a legally binding instrument on all types of forests that would provide a common understanding of what it means to implement sustainable forest management and to include a compliance regime. CCFM members have con- 
sistently contributed to Canada's progress reports on forestrelated matters.

Another successful CCFM initiative has been the International Forestry Partnerships Program (IFPP) established in 1992 and renewed in 2000. The IFPP continues to inform Canada's export markets in Europe, Japan and the United States about Canadian forestry policies, practices, initiatives and achievements to offset any incomplete or inaccurate information that could have an adverse effect on the international market acceptance of Canada's wood and paper products.

\section{Forest Communities}

Rural and remote communities that rely on the forest-forest-based communities-are key players in the forestry sector and recognized as such by the CCFM under its list of strategic themes. They are the forest industries' primary source of labour and sub-contractors. More than 300 Canadian rural communities greatly rely on the economic activity generated by the wood and paper industries, and nearly 500 more derive a large portion of their revenue from this sector.

Aboriginal people are also demanding meaningful participation in decisions affecting the forest and its use, based on their distinct legal rights and a holistic belief in the interdependency of humans and nature. Aboriginal community leaders believe that involvement in the forest sector is vitally important as a source of employment and revenue generation urgently needed by their rapidly growing communities. The trend toward an enhanced Aboriginal presence in the industry and overall sector is well established, and there is every indication that it will continue.

Forest-based communities are at a crossroads where the strong desire of local interest groups to participate in land use decisions intersects with the considerable expectations of the international community and the Canadian public regarding the stewardship of forest ecosystems. As communities increase their participation in the forest sector, they seek to improve their capacity in this regard.

CCFM members work at local and regional levels to reconcile the interests of the various stakeholders living in forest-based communities and the global, national and provincial societal responsibilities that are vested in their respective governments.

Two CCFM working groups currently focus on meeting these many challenges. The Aboriginal Forestry Working Group, established in 1996, is interested in the models and best practices for supporting Aboriginal participation and business development through partnerships. The Private Woodlot Taxation Task Force works to determine the impact of taxation policies, related to private woodlots, on sustainable forest management practices.

\section{Science and Technology}

Canada is a leader in many fields of forest science and technology (S\&T) and is one of the top five countries in integrating high technology equipment into the work environment. Within Canada, many organizations, government departments, academic institutions, industrial forest research institutes and agencies are involved in forest S\&T.

The CCFM formed an S\&T Working Group in 1997 to discuss forestry $\mathrm{S} \& \mathrm{~T}$ priorities in relation to major policy, trade, economic and environmental and social issues. It also addresses major issues related to future forestry S\&T needs such as direction, partnership and funding; provides a forum for reviewing S\&T data as a component of strategic agendas such as national forest strategies; develops S\&T recommendations for the CCFM on forestry issues and priorities and opportunities in the forest sector; and identifies new S\&T opportunities for cooperation and coordination.

\section{Information and Knowledge}

Much of the available forestry information is held, produced, used and managed by governments in Canada. To further disseminate some of this information, the CCFM created, in 1990, the National Forestry Database Program Steering Committee to establish a comprehensive database on a national level that would form the basis for describing forest management activities in Canada and that would provide timely and credible information to the policy process. In 1999, the CCFM established the National Forest Information System (NFIS) Steering Committee. The NFIS Steering Committee is currently developing a national portal and the infrastructure to provide reliable, consistent, timely and integrated information on sustainable forest management in Canada.

\section{Into the Future}

The cooperation between the federal, provincial and territorial Ministers responsible for forests remains positive and productive. The creation of the CCFM has strengthened this relationship and has been instrumental in demonstrating Canada's performance in sustainable forest management. Dealing with national and international forest issues will be even more challenging in the future. The CCFM will continue to meet any challenges through the concerted effort of all levels of government to work on these issues while respecting their given roles and responsibilities. 